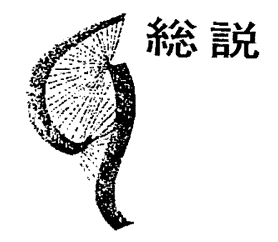

\title{
高分子化学反応の基礎 (続)
}

今日高分子の化学反応に関しては，数多くの研究がなされているが， その基礎的様相は必ずしも明らかでない。著者らは，長年にわたり，ボ り酢酸ビニル，ポリアクリル酸メチルなどを試料に用い高分子エステル のケン化とい5簡単な基礎的な反応について研究を行なってきた。本稿 は，それの総括ともみなすべきものである。高分子の化学反応の最も基 礎的な特徵は反応に参与する分子が大きいということよりか，むしろ， 反応にあずかる官能基が常に隣接グループを持っているということにあ る。この隣接グループは単に立体障害を及ぼすのみでなく，化学反応に あずかる相手を吸着結合し，あるいは反発して，反応速度に大きい影響 を与え，また最高反応度をる支配する。

\section{桜田一郎*}

\section{6. タクチシティーの反応速度に及ぼす影響}

高分子のタクチシティーも化学反応速度に影響を与え るであろうと考えられるが, 1959 年に Glavis ${ }^{19)}$ は種々 のタクチシティーのポリメタクリル酸エステルのアルカ リ媒体中に打けるケン化反応速度を比較し，普通（アタ

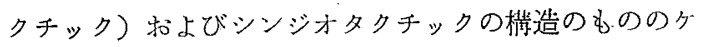
ン化速度は小さいが，イソタクチックのそれは大きく, また高度に進行することを報告した。

Smets と Loecker'20) はシソジオタクチックのポリ タリル酸からつくったメタクリル酸エステルと酸のコポ リマー（A），就よ゙アタクチックとイソタクチックの ポリメタクリル酸メチルの混合物と考えられる試料から 得たエステル酸の共重合物 (B), について, 種々の中和 度に抋いて，緩衝液を用いて加水分解を行ない，ポリマ 一のAは，普通のポリメタクリル酸メチルに比ベて 4 倍 から 5 倍もす又やかに加水分解さ机るが，ポリマーBの 加水分解速度はきわめて遅いことを踤告している。

同様の実験は Smets と Humbeeck ${ }^{21)}$ がアクリル酸 の共重合物について行なっている。アクリル酸とメタク リル酸エステルの共重合物の場合には, インタクチック 系の方が，普通のむのに比べて 3 倍から 5 倍も寸みや柿 にケン化された。

\section{6-1. ポリ酢酸ビニルの加水分解}

これについては，われわれの研究室で行なわれたポり 酶酸ビニルのアルカリケン化速度に及洔すタクチシティ 一の影響22について述べる。

試料としては, イソタクチックのポリビニルエーテル

\footnotetext{
* Ichiro SAKURADA 日本学士院会員 同志社大学教 授. 工博
}

Some Fundamental Aspects of Polymer Reactions
から得られたポリ酶酸ビニル，普通（アタクチック）の ポリ酢酸ビニル，ポリ（トリフルオロ酢酸ビニル）から 得たポリ酢酸ビニル，ポリビニルブチラールから得たポ リ酢酸ビニルなどを用いた。ケン化反応は $\mathrm{NaOH}$ を触 媒に用い,アセトンー水(容積比 $7: 3$ )の中で行なった。

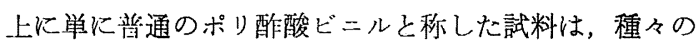
ビニルェステルを種々の温度で重合させて得られたポリ マーを出発物とする 8 種類のポり酢酸ビニルに対する総 称である。ケン化時間と，ヶン化率の関係曲線は第 11 図にボした。

8 種類のポリ酢酸ビニル試料と，ポリ（トリフルオロ 酢酸ビニル）から得られたポリ酢酸ビニルのケン化反応 の経過は 1 本の曲線で示すことができるが, イソタクチ ックのポリ酢酸ビニルならびに，ポリビニルブチラール から得られたポり酢酸ビニルの曲線は，いずれも普通の

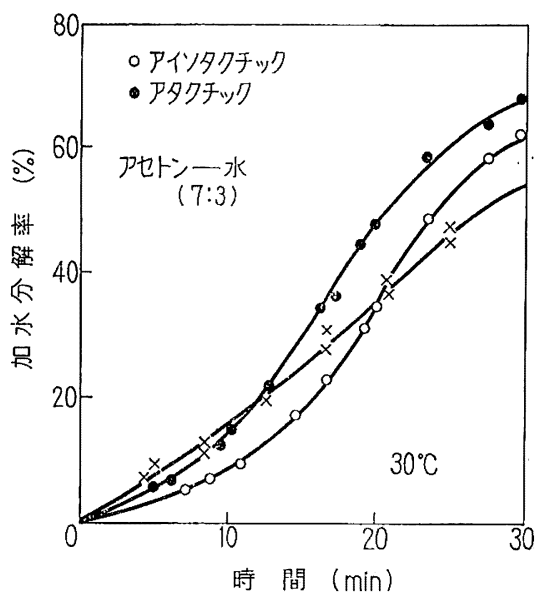

第 11 図 種々のタクチシティーのポリ酢酸ビ ニルのアルカリケン化

Vol. 17, No. 192 
第4 表 タクチシティーを異にするポリ酢酸 ビニルの加水分解速度

\begin{tabular}{l|c|c}
\hline \multicolumn{1}{c|}{ タクチシティー } & $k_{0}$ & $m$ \\
\hline イソタクチック & 0.14 & 49 \\
アタクチック & $0.23,0.21$ & 39,38 \\
“頭と頭”結合に富む試料 & 0.50 & 5.6 \\
\hline
\end{tabular}

ポリ酢酸ビニルに刘するそれと，大きく異なっている。 初速度定数 $k_{0}$ と自己触媒能の指標である $m$ の数值を示 すと第 4 表のごとくである。シンジオタクチックポリマ 一に対する赛験は残念ながらまだ行なわれていない。

ポリビニルブチラールから得られた試料の楧造は宋だ 明りょらでない。しかし，ポリビニルアルコールの形に してとったこの試料の赤外スペクトルは普通のポリビニ ルアルコールのそれといくぶん異なっている。かいわ れわれは, この試料はシンジオタクチック構造に富んで いると考えた。しかし，最近の未発表の研究によると， 普通のポリビニルアルコールは, “頙と尾”型の結合が 圧倒的に多いのに対して，この試料は “頭と頭”型絬合 飞富んでいると考皇た方がより妥当な上らである。

第 4 表より明らかなように, 初期速度は, アタクチッ クポリマーの方が，イソタクチックポリマー上り大き い，一方前者の $m$ は後者のそ机上り小さい。アタクチ ック構造に㧊いては，イソタクチック構造に比べて，ア 七チル基間の距離は大であるから，立体障害はより少な い。したがってアタクチックポリマーの $k_{0}$ は大きい。 ケン化がある程度進むと,イソタクチック構造に淤ける 方が，他上りも，アセチ儿基と水酸基，したがってアセ チル基と吸着されたイオンとの距離は小さく、イソタク チックポリマーの方が大きい $m$ を示すことになる。

上の三つのグループの試料についてアセタール化反応

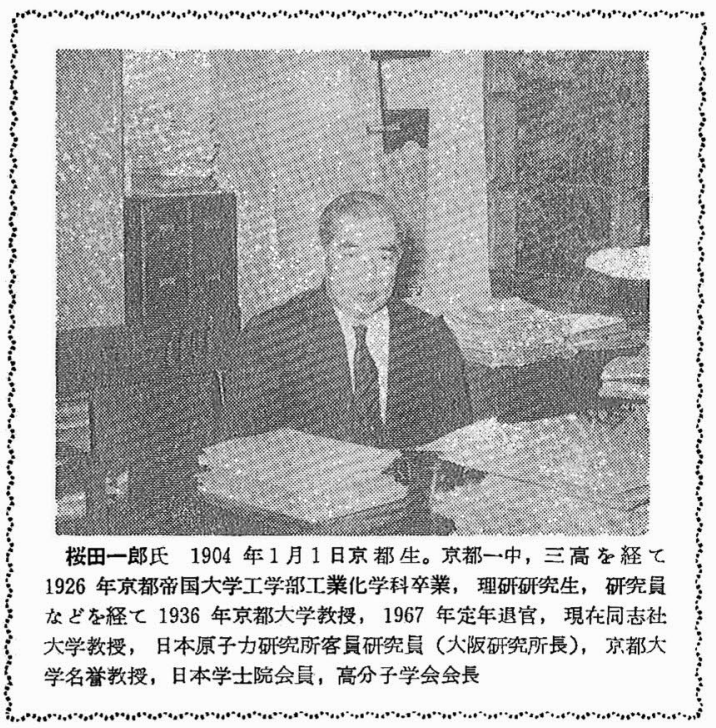

[208]

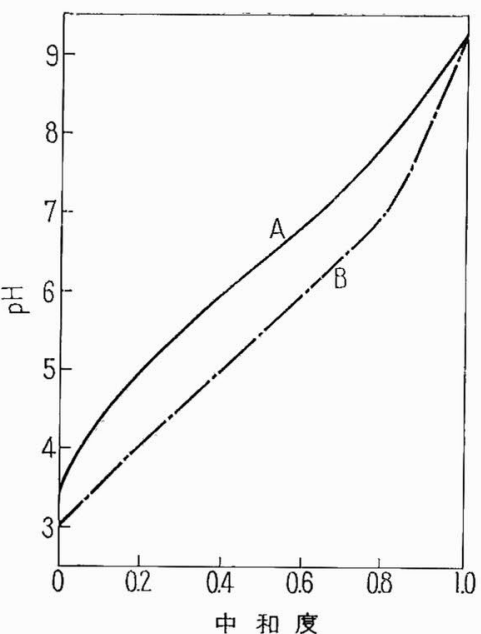

$\mathrm{COOH} 0.010 \mathrm{~N}, 20^{\circ} \mathrm{C}$

第 12 図 ポリアクリル酸の滴定曲線

(A 普通の試料， B 特別の試料)

も比較した。第 5 表にはアセタール化の平衡定数を示し たが，この場合にも三つのグループの間に大きい反応性 の差のあることが楒められた。

第 5 表 タクチシティーを異にするポリビニル アルコールのアセタール化平衡定数

\begin{tabular}{c|c}
\hline \hline タクチシティー & 平衡定 数 \\
\hline イソタクチック & 3,100 \\
アタクチック & $1,200,1,400$ \\
“頭と頭”結合に富む試料 & 17 \\
\hline
\end{tabular}

\section{6-2. ポリアクリル酸メチルの加水分解}

われわれは以前に23)，アクリル酸エステルの種々の条 件下に拈けるラジカル重合物をケン化して得られたポり アクリル酸および，アクリル酸を種々の条件下にラジカ 儿重合して得られたポリアクリル酸など十数種類の試料 につき中和滴定曲線を求めて比校した。その結果は第 12 図に示寸ごとく 1 個の例外を除き，他はすべて，実 駩䛊散内で 1 本の滴定曲線で示されることを知った。

この例外のポリアクリル酸といらのは, アクリル酸の 重合を，生長鎖の末端とモモーー間の静電的反発が大 きいよらな条件で行ない得られたものである。すなわち， そ机は溶剤 水一ェタノール (95:4), モノマー濃度 $1 \%$, 開始剤アゾビスイソブヂロニトリル，液の $\mathrm{pH}$ を 7 亿保 ち，重合温度は $60^{\circ} \mathrm{C} て ゙$ 得られたものである。この重合 条件で得られたポリアクリル酸の中和曲線は，図上り明 らかなように，显通のアクリル酸の中和州線の上飞位置 している。重合条件や滴定曲線の位置から，われわれは この例外的なポリアクリル酸はシンジオ構造に富んでい るものと考克た。

次にここ机らの種々のポリアクリル酸をメチルェステ 


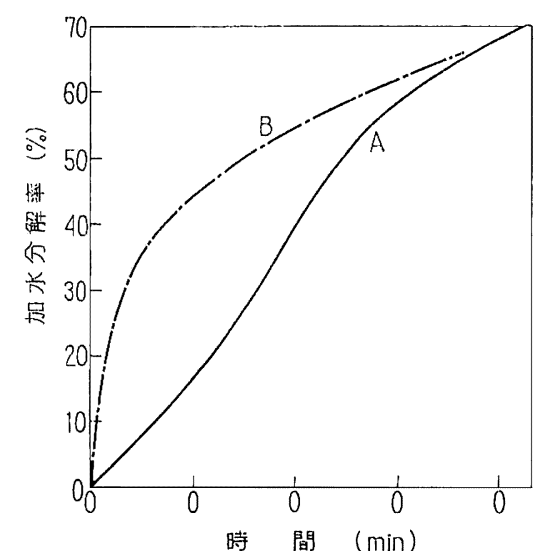

A: $\quad k_{0}=0.09 l \cdot \mathrm{mol}^{-1} \cdot \mathrm{min}^{-1}$ B: $\quad k_{0}=1.7 l \cdot \mathrm{mol}^{-1} \cdot \mathrm{min}^{-1}$ ポリマー 0.059 基本 $\mathrm{mol} / \mathrm{l}$ $\mathrm{NaOH} 0.059 \mathrm{~mol} / \mathrm{l}$ アセトンー水 $(7: 3), 30^{\circ} \mathrm{C}$

第 13 図 ポリアクリル酸メチル加水分解 （A 普通の試料， B 特別の試料）

ルに变え,アセトンー水（容積比 7:3）中でケン化を行 ない, 反応曲線を比較した。結果は第 13 図に示すごと 々，滴定曲線に対応し皆通のポリアクリル酸のケン化反 応の進行はすべて 1 本の曲線で示されるが，シンジオ構 造に富む試料のそれのみは別の曲線となった。

普通捕よびシンジオに富むポリマーのケン化反応の初 速度定数はそれぞれ 0.09 お。よび $1.71 \mathrm{~mol}^{-1} \cdot \mathrm{min}^{-1}$ で あった。後者の $1.71 \mathrm{~mol}^{-1} \cdot \mathrm{min}^{-1}$ なる值は, 第 2 表に 示した methyl isobutyrate に対する值と，ほぼ一致す る。この結果から教るると、シンジオタクチック構造で はポリアクリル酸メチルのエステル基は，より孤立した 状態にあり隣接基の立体障害的影響を受けることが少な 々，類似の構造の低分子ェステルとよく似た反応を示す ものと思われる。

\section{7. 高分子の化学反応における疎水性相互作用 ${ }^{25)}$}

\section{7-1. 高分子スルホン酸によるェステルのケン化}

近時われわれの研究室に拈ける研究に上り，高分子の 化学反応に执いて, 眯水性相互作用が大きい役割を演じ ることが明らかになった。その第 1 の例は, ポリスチレ ソスルホン酸のような高分子スルホン酸に上る低分子エ ステルのケン化である。

塩酸のような低分子酸を触媒に用いて，低分子ェステ ルをケン化する場合には，エステル分子も酸分子も溶液 中に均一に分散され，反応は，反応系のどこに拈いて子均 一起こりらると考えることができる。他方高分子スル ホン酸を触媒に用いるときには，スルホン基の対イオン である水素イオンは全部高分子の近所にだけ存在してい る(第 14 図 a 参照)。高分子の近所以外には, 水素イオ ンはケン化反応を起こしうる程度の濃度には存在してい

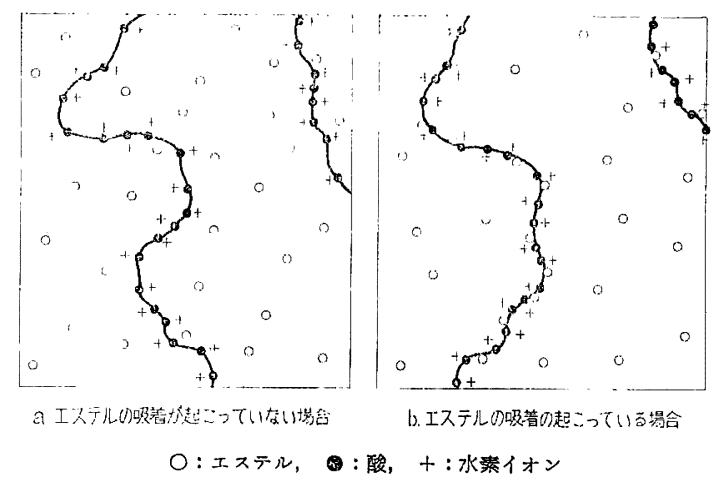

第 14 図 低分子ェステルの高分子スルホン酸 飞上る加水分解

ないから化学反応は高分子の存在する場所以外において は起こりえない。もし，この場合に低分子ェステルが， 系全体に均一に分配されておれば，反応速度は見かけ上， 低分子酸を触媒に用いたときと变わりがない。というの は，実際に反応の起こりらる筀間が少なくなったという ことは, 反応の起こりらる場所で水素イオン濃度が高く なったことによって，正碓に補なれれるからである。も しェステル分子が高分子スルトン酸に吸着されれば，事 情は変化してくる（第 14 图b参照）。この場合にはち ょらど水素イオン溦度の高い場所でェステルの濃度も高 くなる。このような暘合には高分子スルホン酸は，低分 于の塩酸や硫酸などより，上り大きい見か计の速度定数 炎与党るであるらと教えられる。

実験としては，ポリスチレンスルホン酸によるェステ ルのケン化反応速度を，塩酸による关れと比校した。使 用したポリスチレンスルホン酸は, スチレンスルホン酸 モノマーの重合によって得られたポリスチレンスルホン 酸 (PSS) と,ポリスチレンのスルホン化物 (PS-S) であ り, PS-Sのスルホン化度は 23 から $77 \mathrm{~mol} \%$ の間であ る。典型的な実験として，酶酸メチルおよび酢酸 $n$ ーブ チルのケン化反応を，PSS おょび PS-S を用いて行な い塩酸によるケン化と比校した例を第 6 表に示す。表の 最後の行のては，高分子スルホン酸に上る見かけり速度 定数と塩酸によるそれの比である。すなわち $r=k / k \mathrm{HCl}$ である。

第 6 表より明らかなように，眽酸メチルはポリスチレ ンスルホン酸により塩酸によるょりも大きい速度でケン 化される。この此較は, 同一のスルホン基の浱度で行な っている才壮であるが，スルホン化度の低い方がより強 い触媒であることがわかる。このことは，スルホン化さ れていないベンゼン環が，協同效果を発揮していること を物語るものである。

酢酸 nーブチルは，醀酸メチルより長いアルキル基を もっており，ヶン化に対与る举動は定性的には雨者同じ であるが，高分子触媒の効果は，䣫酸 $n$-ブチルに対す 
第 6 表 酢酸メチル拈よび䣫酸 $n$-ブチルの水中に拉けるポリスチレン スルホン酸に上る加水分解

\begin{tabular}{|c|c|c|c|c|}
\hline \multirow{2}{*}{$\begin{array}{l}\text { 触 媒 } \\
\text { （）中の数字はスル } \\
\text { ホン化度 }(\mathrm{mol} \%) を \\
\text { 意眛する }\end{array}$} & \multicolumn{2}{|c|}{$\begin{array}{l}\text { 䣫酸メチル } \\
\text { エステル濃度： } 2.50 \times 10^{-2} \mathrm{M} \text {; } \\
\text { 触媒濃度： } 5.00 \times 10^{-3} \mathrm{~N} ; \\
\text { 温 度： } 40^{\circ} \mathrm{C}\end{array}$} & \multicolumn{2}{|c|}{$\begin{array}{l}\quad \text { 酢酸 } n \text {-ブチル } \\
\text { エステル濃度： } 2.85 \times 10^{-2} \mathrm{M} \text {; } \\
\text { 触媒濃度： } 5.00 \times 10^{-3} \mathrm{~N} ; \\
\text { 温 } \quad \text { 度： } 40^{\circ} \mathrm{C}\end{array}$} \\
\hline & $\begin{array}{c}k \times 10^{2} \\
\left(l \cdot \mathrm{mol}^{-1} \cdot \mathrm{min}^{-1}\right)\end{array}$ & $r$ & $\begin{array}{c}k \times 10^{2} \\
\left(l \cdot \mathrm{mol}^{-1} \cdot \mathrm{min}^{-1}\right)\end{array}$ & $r$ \\
\hline $\mathrm{HCl}$ & 2.31 & 1.00 & 2.30 & 1.00 \\
\hline PSS & 2.39 & 1.03 & 4.42 & 1.92 \\
\hline PS-S (77) & 2.79 & 1.21 & 5.91 & 2.57 \\
\hline PS-S (65) & 3.25 & 1.41 & 6.94 & 3.02 \\
\hline PS-S (52) & 3.53 & 1.53 & 10.35 & 4.50 \\
\hline PS-S (40) & 3.63 & 1.57 & 14.5 & 6.31 \\
\hline PS-S (33) & 4.86 & 2.10 & 18.3 & 7.96 \\
\hline PS-S (23) & 5.06 & 2.19 & 23.5 & 10.22 \\
\hline
\end{tabular}

第 7 表 酢酸 $n$-ブチルの ポリスチレンスルホン酸 による加水分解速度に及ほすすアセトン涯加の 影響（エステル濃度： $2.85 \times 10^{-2} \mathrm{M}$, 触媒濃 度 $5.00 \times 10^{-3} \mathrm{~N}$, 温度： $40^{\circ} \mathrm{C}$ )

\begin{tabular}{c|c|c}
\hline \hline \multirow{2}{*}{$\begin{array}{c}\text { アセトの容積 } \\
(\%)\end{array}$} & \multicolumn{2}{|c}{ 下記触媒に対する $r$} \\
\cline { 2 - 3 } & PS-S(40) & PSS \\
\hline 0 & 6.31 & 1.92 \\
15 & 2.61 & 1.48 \\
30 & 1.55 & 1.12 \\
\hline
\end{tabular}

る方が大きい。

類似の実験を、種々のエステルを用いて，種々の温度

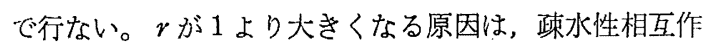
用により，高分子付近のエステル濃度が高くなることに あるとの結論に達した。もし，この結論が正しいならば

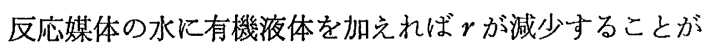
期待される。そこでケン化反応を，純水中で行ならかわ りにアセトンの水溶液で行なった。第 7 表に示す上らに アセトンの添加とともに、は減少した。

このような疎水性相互作用は，高分子スルホン酸であ れば，その構造に無関係に認められるかといえば，そう ではない。強い蹯水性のグループを持った高分子スルホ ン酸だけが，蹯水性相互作用を示す。第 8 表には， $r=1$ の高分子スルホン酸， $r>1$ の高分子スルホン酸の例を 示した。

エステルの高分子に対する吸着を，实際に証明し，吸 着量と，触媒効果の関係を明りょにするために，クロス リンクしたスルホン化ポリスチレンを用いて実験を行な った ${ }^{26)}$ 。実際に使用したのは Dowex 50 で㘯った。H型の樹脂に使えば，ケン化反応が起こり，エステルの四 着量の測定は行なえないからそそれは Na-型の樹脂を用
第 8 表 高分子スルホン酸の触媒作用

A. 低分子酸と異ならない例 $(r \approx 1)$

\begin{tabular}{|c|c|}
\hline PVS & ポリビニルスルホン酸 \\
\hline PVS-VA & $\begin{array}{l}\text { ビニルスルホン酸とビニルアルコールの共 } \\
\text { 重合体 }\end{array}$ \\
\hline PVBS & ポリビニル ブチラールスルホン酸 \\
\hline PVBeS & ポリビニル・ベンザールスルホン酸 \\
\hline
\end{tabular}

B. 低分子酸より大きい触媒効果を示す例 $(r>1)$

\begin{tabular}{|c|c|}
\hline PSS & ポリスチレンスルホン酸 \\
\hline PS-S & ポリスチレンの部分スルホン化物 \\
\hline PVS-S'T & ビニルスルホン酸とスチレンの共重合物 \\
\hline $\mathrm{PAN}-\mathrm{ST}$ & ポリアセナフチレンの部分スルホン化物 \\
\hline PMS-S & $\begin{array}{l}\text { ポリー } \alpha \text {-メチルスチレソの部分スルホン化 } \\
\text { 物 }\end{array}$ \\
\hline PS-Sti-S & $\begin{array}{l}\text { スチレソとスチルベンの共重合体の部分ス } \\
\text { ルホン化物 }\end{array}$ \\
\hline
\end{tabular}

いて実験した。 $C_{0}$ を系の最初のエステル濃度, $C_{i}$ を樹 脂相に和けるエステル濃度とすれば， $C_{i} / C_{0}$ は高分子付 近におけるェステルの濃縮化の指標になる。Na-型で測 定した $C_{i} / C_{0}$ と， H型で測定した $r$ を比校して示したの が第 9 表である。表からわかるように, $r$ の值と $C_{i} / C_{0}$ の值の間には密接な平行関係がある。したがって，大き

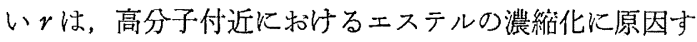
るといら説明は決定的な支持を得たといらことができ る。

この機会に高分子スルホン酸によるェステルの加水分 解の祭に扣壮る静電的相互作用について一言する。

もし，加水分解の垁験にェステルとしてアミノ酸のエ ステルを使用すれば，高分子触媒付近のェステル濃度は スルホン酸グループとアアミノ基の間の相互作用によ。 
第9表 クロスリンクしたスルホン化ポリスチレン のエステル吸着能 $C_{i} / C_{0}$ と, 接触作用の效 果 $r$ との比較 $\left(40^{\circ} \mathrm{C}\right)$

\begin{tabular}{|c|c|c|c|c|c|c|}
\hline エステ & U ル & $\begin{array}{l}\text { 酢酸 } \\
\text { メチル }\end{array}$ & $\begin{array}{c}\text { 酢酸 } \\
n \text {-ブチ } \\
\text { ル }\end{array}$ & $\begin{array}{c}\text { 䣫酸 } \\
t \text {-ブチル }\end{array}$ & $\begin{array}{l}\text { 䣫酸 } \\
フ \text { フェ } \\
=ル\end{array}$ & $\begin{array}{l}\text { 酩酸 } \\
\text { ヘキ } \\
\text { シル }\end{array}$ \\
\hline $\begin{array}{l}\text { Dowex } \\
\mathrm{W} \times 2\end{array}$ & $\begin{array}{c}C_{0}^{*} \\
C_{i}^{*} \\
C_{i} / C_{0} \\
r\end{array}$ & & $\begin{array}{l}0.0305 \\
0.0863 \\
2.83 \\
2.70\end{array}$ & $\begin{array}{l}0.0295 \\
0.0758 \\
2.57 \\
1.74\end{array}$ & & \\
\hline $\begin{array}{r}\text { Dowex } \\
W \times 4\end{array}$ & $\begin{array}{c}C_{0}^{*} \\
C_{i}^{*} \\
C_{i} / C_{0} \\
r\end{array}$ & $\left|\begin{array}{l}0.0504 \\
0.0814 \\
1.62 \\
1.52\end{array}\right|$ & $\begin{array}{l}0.0305 \\
0.0956 \\
3.13 \\
2.90\end{array}$ & $\begin{array}{l}0.0295 \\
0.0804 \\
2.73 \\
1.84\end{array}$ & $\begin{array}{l}0.0157 \\
0.0789 \\
5.02 \\
6.30\end{array}$ & $\begin{array}{l}0.0136 \\
0.0721 \\
5.30 \\
4.70\end{array}$ \\
\hline
\end{tabular}

* $C_{0}$ 括よび $C_{i}$ の単位注 $\mathrm{mol} / \mathrm{l}$

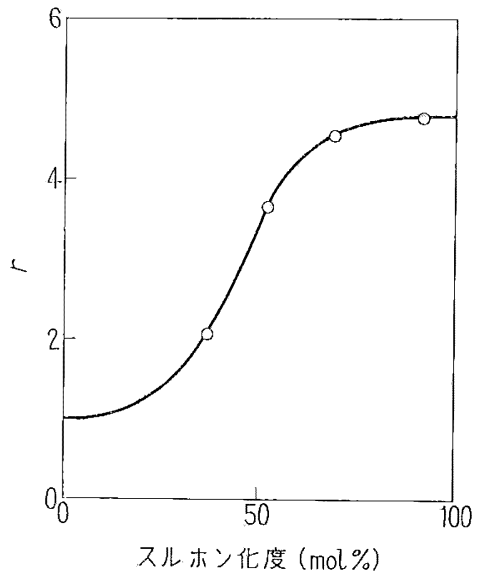

第 15 図 パラアミノ安息香酸の $50 \%$ アセトン水 溶液中に括けるポリスチレンスルホン酸に 上る加水分解(触媒濃度 $0.05 \mathrm{~N}$, エステル 濃度 $0.08 \mathrm{M}$, 温度 $80^{\circ} \mathrm{C}$ )

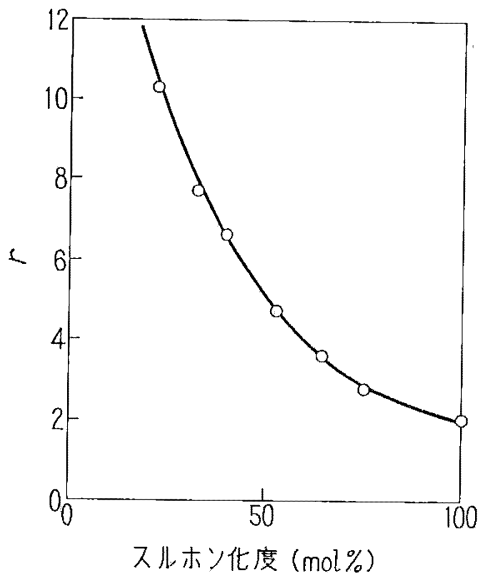

第 16 図 醀酸nーブチルのポリスチレンスルホン 酸による水溶液中での加水分解（触媒濃 度 $0.05 \mathrm{~N}$; エステル濃度 $0.0285 \mathrm{M}$; 温 度 $40^{\circ} \mathrm{C}$ )
て上昇し，そのために高い扣水分解速度が見出されるで あるうと期街できる。

実験は， 0 -拈よび $p$-アミノ安息香酸を用い $50 \%$ のア セトン溶液中で行なった。初速度定数 $k_{0}$ は実験結果の 外挿により求めた。結果は第 15 図に示すようである。 期待どおり $r$ は大きい值を与える。PS-S のスルホン化 度の增加に伴い $r$ が大きなるといらこは特に注目すべ さであり，スルホン化度の増加とともにっが小さくなっ た疎水性相互作用の場合子正に反対である。孤立したス ルホン酸グループが，rの增大に笴与しているとすれば， この事実性解しにくい。といらのは，低スルホン化度 のポリスチレンのスルホン酸グループの接触作用は塩酸 のそれと，添とんど同じであるからである。大きいrを 示すのには，スルホン酸グループの何個かの連続が必要 であるよらに思われる。

7-2. 長鎖アルキルあるいは長鎖アルキルベンゼンス ルホン酸による高分子エステルのケン化 27

次には，上に述べた例と反対の場合を取り扱う。すな わち，エステルは高分子であり，触媒は低分子の長鎖了 ルキルあるいは長鎖アルキルベンゼンスルホン酸の場合 である(第 17 図参照)。実験は主として水溶性の部分

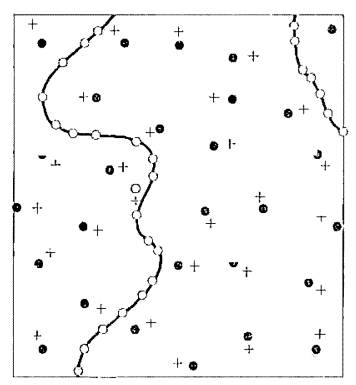

、.スルホン醉の吸着が起こっていない場合

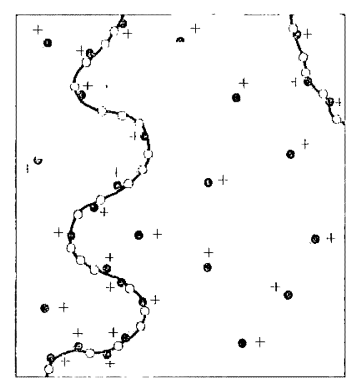

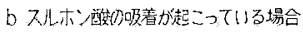

第 17 図 高分子ェステルの低分子スルホン酸 以上る加水分解

第 10 表 部分酢化ポリビニルアルコールの低分子 スルホン酸による加水分解

\begin{tabular}{|c|c|c|c|c|}
\hline \multirow[t]{2}{*}{ 触虽 } & \multirow{2}{*}{$\begin{array}{l}\text { 触媒 } \\
\text { 濃度 } \\
(N)\end{array}$} & \multirow{2}{*}{$\begin{array}{l}\text { 温度 } \\
\left({ }^{\circ} \mathrm{C}\right)\end{array}$} & \multicolumn{2}{|c|}{$\begin{array}{l}\text { 下記の酢化度 } \\
(\text { mol\%)のポリ } \\
\text { ビニルアルコー } \\
\text { ルル対するr }\end{array}$} \\
\hline & & & 9.21 & 23.333 .6 \\
\hline オクチルスルホン酸 & 0.010 & 40 & 1.1 & 1.11 .3 \\
\hline ドデシルスルホン酸 & " & $"$ & 12.5 & 13.512 .4 \\
\hline ヘキサデシルスルホン酸 & " & " & - & 19.122 .1 \\
\hline ドデシルベンゼンスルホン酸 & " & " & 20.7 & \begin{tabular}{ll|l}
20.6 & 20.7
\end{tabular} \\
\hline ドデシルスルホン酸 & 0.0050 & 50 & 10.4 & 9.310 .8 \\
\hline ヘキサデシルスルホン酸 & " & " & 19.3 & $20.0-$ \\
\hline オクタデシルスルホン酸 & " & " & 一 & 19.122 .1 \\
\hline ドデシルベンゼンスルホン酸 & $"$ & " & 19.3 & 16.719 .9 \\
\hline
\end{tabular}


酢化ポリビニルアルコールを用いて行なった。結舆は第 10 表に示したごとくである。

第 10 表からわかるよらに，オクチルスルホン酸の の值は 1 に近く，したがってその触媒としての効棵はほ とんど塩酸のそれと同一である。しかし，それより高級 なドデシルー, ヘキサデシルー, オクタデシルーあるいは ドデシルベンゼンスルホン酸の場合にはrは1よりはる かに大きい。このように大きい $r$ を觉る原因は，高分 子ェステルの付近に打いて践水性相互作用により長鎖了 ルキルあるいはアルキルベンゼンスルホン酸の濃度が高 くなったことにあるらと思われる。その結果としてェス テルの濃度の高い場所において水素イオン濃度が高くな り，反応速度は大いに上昇したわけである。

7-3. 高分子エステルの高分子スルホン酸によるケン 化 ${ }^{28)}$

最後に，高分子ェステルの高分子スルホン酸によるク ソ化に関し簢単に述ベる。もし，蹯水性相互作用が存在 与れば, エステルも触媒も雨者とも高分子の場合には, その效果はいっそら顕著になるであろうと考えられる。 実験は，この場合にもエステルとしては水溶性の部分酢 化ポリビニルアルコール, 触媒としてポリスチレンスル ホン酸を用いて行なった。実験の詳細和よび結果は第11 表に示したごとくである。表より明らかなよらに,す ベての部分眼化ポリビニルアルコールに対し，ポリスチ レンスルホン酸は大きいrを与文るここの場合に見壮さ 机た最大の て, ポリスチレンスルホン酸は塩酸の 40 倍もの损触能 力を有することを意味する。酶酸化度の增加に伴い $r$ 当

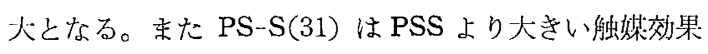
を発揮する。さらに，䣫酸基の長い連続からできている 部分酭化ポリビニルアルコールの力が，ランダムに酢化 されたポリビニルアルコールより大きい れらの事実はすべて, 部分酢化ポリビニルアルコールの アセチル基とポリスチレンスルホン酸のベンゼン核の間 の疎水性相互作用がケン化反応において大きい役割を演 じることを物留るものである

結論として, 高分子の化学反応の最も重要な特徵は,
第 11 表 部分酶化ポリビニルアルコールのポリス チレンスルホン酸に上る加水分解（基質 濃度： $3.0 \mathrm{~g} / l$, 触媒濃度, $0.0050 \mathrm{~N}$, 温, 度: $50^{\circ} \mathrm{C}$ )

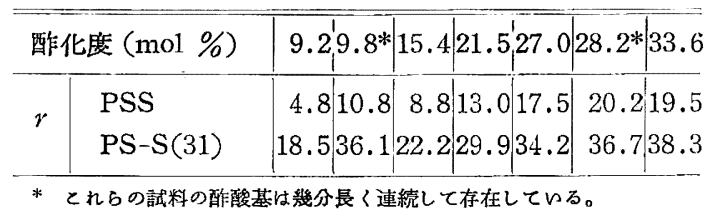

分子が大きいということそれ自身ではなく，分子が常 に瞵接 グループを持っていることにあるといらことを 強調したい。ある場合には，これらの隣接グループは Morawetz, Smets らが指摘したように, 官能基との間 に特異の相互作用をする。しかし，隣接基と反応相手の 分子間の親水性, 静電気的特に疎水性相互作用の方が, より一般的でありしたがって基礎的により垂要である。

\section{文献}

1) P. J. Flory: J. Am. Chem. Soc., 61, 3334 (1939); K. Freudenberg, W. Kuhn, W. Dürr, F. Bolz, G. Stein brunn: Chem. Ber., 63, 1510 (1930)

2) 大杉鉄郎：合成繊維研究，2，192(1944); 桜明一 郎：高分子展望，5，64（1951）

3) A. Conix, G. Smets: J. Polymer Sci., 15, 221 (1955)

4）桜田一郎, 坂口康義, 福井節也：高化，13，355, 361,408 (1956)

5）桜田一郎, 坂口康義, 福井節也：高化, 17, 83 (1960)

6）桜田一郎, 坂口康義：高化，13，441 (1956); 桜 田一郎, 坂口康義, 石黑薰孝: 高化, 17, 115 (1960)

7) 長井栄一, 相根典男：高化，12，195（1955）

8）桜田一郎, 坂口康義, 加賀 宇: 高化, 17,87 (1960)

9) A. Kachalsky, N. Shavit, H. Hisenberg: J. Polymer Sci., 8, 69 (1954)

10）桜田一郎，野間夹之，加藤 鼠：高化 $15 ， 799$ (1958)

\section{レオロジーハンドブック 高分子学会編 \\ A 5 判 892 ページ 6000 円 丸善(株)発行}

当学会編集の「レオロジーハンドブック」は会員に限り一割引で扮頒らすることができ ます。ご希望の方は直接学会あてに招申し込み下さい。

な执，木書に対する内容紹介は「高分子」Vol. 14, No. 162, 778 ページの書評をごら ん下さい。 
11）高化に発表予定

12) R. C. Schulz: Makromol. Chem., 42, 205 (1961)

13) H. Morawetz, P. E. Zimmering: J. Phy. Chem., 58, 753 (1954)

14) P. E., Zimmering, E. W. Westhead, Jr., H. Morawetz: Biochem. Biophys. Acta, 25, 376 (1957); Chem. Abstr., 51, 16617 d (1957)

15) W. De Loecker, G. Smets: J. Polymer Sci., 40, 203 (1955); G. Smets, W. De Loecker: J. Polymer Sci., 41, 375 (1959); 45, 461 (1960)

16）野間夫之, 沢頭長之: 高化，4，46(1947)

17）野間夫之, 黄 天平, 常田隆博: 高化, 6, 439 (1949)

18）桜田一郎, 坂口康義，大村恭弘：高化，21，564 (1964)

19) F. J. Glavis: J. Polymer Sci., 36, 547 (1959)
20) G. J. Smets: J. Polymer Sci., 45, 461 (1960)

21) G. J. Smets: Angew. Chem., 74, 337 (1962)

22）桜田一郎，坂口康義，椎木善弥，西野·潤：高化， 21, 241 (1964)

23）桜田一郎, 坂口康義： Markromol. Chem., 61, 1 (1963)

24）桜田一郎，坂口康義，岩垣武久，三葛康也：高化， 21, 426 (1964)

25) I. Sakurada, Y. Sakaguchi, T. Ono, T. Ueda Makromol. Chem., 91, 243 (1966)

26）桜田一郎, 坂口康義, 小野友義, 桑原宣彰: 高化, 24, 130 (1966)

27) I. Sakurada, Y. Sakaguchi, Y. Omura: Bull. Inst. Chem. Res., Kyoto University, 43, 149 (1965)

28) I. Sakurada, Y. Sakaguchi, Y. Omura: Bull. Inst.Chem. Res., Kyoto University, 44, 135 (1966)

\section{高分子学会講演要旨集実費頒布}

下記要旨集は残部が多少ございますのでおわけします。氏名・送付先を明記し，代金をそえて 高分子学会講演会係に拈申込2下さい。

\begin{tabular}{|c|c|c|c|c|c|}
\hline 行 & 開催 年月 & 大きさ & 印 刷 方 法 & $\mid$ ページ数 $\mid$ & 頒価（送料とも） \\
\hline 重合反応工学討論会 & 43 作 1 月 & B 5 & オフセット & 24 & 300 円 \\
\hline M. Goodman 講演会 & 43 年 1 月 & B 5 & タイプ & 15 & 200 円 \\
\hline 高分子機械材料ゼミナール & 42 年 11 月 & B 5 & オフセット & 70 & 700 円 \\
\hline '67 年秋季印刷適性請演会 & 10 月 & B 5 & " & 22 & 500 円 \\
\hline 第 16 回レオロジー討論会 & 9 月 & B 5 & " & 192 & 1100 円 \\
\hline 第 12 回静電気研然発表会 & 6 月 & B 5 & " & 78 & 955 円 \\
\hline 重合反応工学講演会 & 5 月 & B 5 & " & 12 & 125 円 \\
\hline 静電気講習会 & 4 月 & B 5 & $"$ & 58 & 545 円 \\
\hline 紙の加工に関する講演会 & 3 月 & B 5 & オフセット & 42 & 345 円 \\
\hline 第 15 回高分子討諭会 & 41 年 11 月 & B 5 & オフセット & 486 & 1100 円 \\
\hline 高分子機栈材料ゼミナーール & 11 月 & B 5 & " & 78 & 555 円 \\
\hline $\begin{array}{l}\text { Preprints of Scientific } \\
\text { Papers (Internotional } \\
\text { Symposium on Macromo- } \\
\text { lecurar Chemistry, Tokyo } \\
\text {-Kyoto, 1966) 全 } 6 \text { 冊(英文) }\end{array}$ & 9,10 月 & B 5 & タイプ・オフセット & 1427 & 3600 円(送料別 \\
\hline $\begin{array}{l}\text { Polymer Industry in Japan } \\
\text { (英文) }\end{array}$ & 9 月 & A 4 & オフセット & 268 & 2000 円 \\
\hline 調湿と乾燥講習会 & 40 年 11 月 & B 5 & タイプ & 64 & 545 円 \\
\hline 第 9 回 高分子と水討論会 & 11 月 & B 5 & " & 52 & 335 円 \\
\hline 多成分系のレオロジー講座 & 11 月 & B 5 & " & 72 & 545 円 \\
\hline 射出成形講習会 & 5 月 & B 5 & " & 68 & 545 円 \\
\hline
\end{tabular}

